\title{
Synthesis and antimicrobial activity of some bromo-benzothiazolo pyrazolines
}

\author{
Bharat Kumar ${ }^{1}$, Vishal Pathak ${ }^{3}$, Sushma Rani ${ }^{2}$, Ravi Kant ${ }^{4}$, Tewari I.C. ${ }^{1 \star}$ \\ ${ }^{1}$ Department of Chemistry, D.B.S. (P.G.) College, Kanpur, 208001, U.P. \\ ${ }^{2}$ Department of Chemistry, D.G. (P.G.) College, Kanpur, 208001, U.P. \\ ${ }^{3}$ Department of Chemistry, Paliwal (P.G.) College, Shikohabad, 205135, U.P. \\ ${ }^{*}$ Department of Medicinal Chemistry, M.G.I.P., Lucknow, 227101, U.P.
}

\begin{abstract}
The present investigation was carried out to study the effect of bromine on the biological activity of pyrazolines. Some previously synthesized substituted pyrazolines were brominated by bromine in acetic acid. The synthesized bromo-benzothiazolopyrazolines were characterized by elemental analysis, IR and PMR spectra. The synthesized bromo-benzothiazolopyrazolines were subjected to in-vitro antimicrobial activity against various pathogenic bacteria.
\end{abstract}

\section{Introduction}

Pyrazolines or di-hydro pyrazoles/Pyrazolines derivatives have been studied extensively because of their ready accessibility, diverse chemical reactivity and broad spectrum of biological activity. Literature survey reveals that several workers have synthesized pyrazolines by addition reactions of hydrazine [1], phenyl hydrazine [2] and 2, 4-dinitrophenylhydrazines [3] with chalcones. Antibacterial activity of some fluorine containing 2-Pyrazolines has been studied recently [4]. In view of the influence of halogen atoms on the biological activity of organic compounds [5], Ankhiwala [6] synthesized some nuclear halogenated pyrazolines and their derivatives and screened them for their biological activity. In continuation of our previously synthesized pyrazolines [7], we have now synthesized bromopyrazolines by the bromination of pyrazolines to study the effect of bromine on their biological activity.

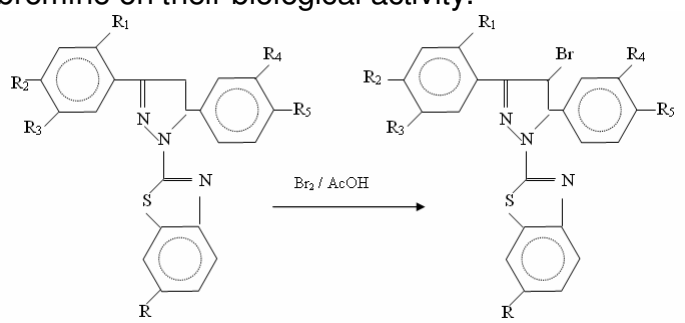

Where,

$\mathrm{R}=\mathrm{CH}_{3}, \mathrm{R}_{1}=\mathrm{R}_{2}=\mathrm{R}_{3}=\mathrm{R}_{4}=\mathrm{R}_{5}=\mathrm{H}$

$\mathrm{R}=\mathrm{OCH}_{3}, \mathrm{R}_{1}=\mathrm{OH}, \mathrm{R}_{2}=\mathrm{R}_{3}=\mathrm{R}_{4}=\mathrm{H}, \mathrm{R}_{5}=\mathrm{Cl}$

$\mathrm{R}=\mathrm{OCH}_{3}, \mathrm{R}_{1}=\mathrm{H}, \mathrm{R}_{2}=\mathrm{Cl}, \mathrm{R}_{3}=\mathrm{R}_{4}=\mathrm{H}, \mathrm{R}_{5}=\mathrm{Cl}$

$\mathrm{R}=\mathrm{CH}_{3}, \mathrm{R}_{1}=\mathrm{H}, \mathrm{R}_{2}=\mathrm{CH}_{3}, \mathrm{R}_{3}=\mathrm{H}, \mathrm{R}_{4}=\mathrm{R}_{5}=$ $\mathrm{OCH}_{3}$

$\mathrm{R}=\mathrm{OCH}_{3}, \mathrm{R}_{1}=\mathrm{OH}, \mathrm{R}_{2}=\mathrm{R}_{3}=\mathrm{R}_{4}=\mathrm{R}_{5}=\mathrm{H}$

\section{Experimental procedure}

All chemicals and solvents used in the present investigation were BDH products. Melting points were determined in open capillary tubes and are uncorrected. IR spectra were recorded in $\mathrm{KBr}$ on Perkin-Elmer 577 spectrophotometer and NMR spectra on an AC 300F spectrophotometer with $\mathrm{CDCl}_{3}$ using TMS as internal references (chemical shift in $\delta \mathrm{ppm}$ ). Purity of the compounds was checked on TLC using silica gel-C.

\section{Synthesis of 3, 5-diphenyl-1-(6- methylbenzothiazolo)-4-bromopyraxolines (I)}

The 3, 5-Diphenyl-1-(6-methylbenzothiazolo) pyrazoline $(0.62 \mathrm{~g})$ was dissolved in hot acetic acid $(40 \mathrm{ml})$. After cooling bromine $(0.3 \mathrm{ml})$ in acetic acid $(10 \mathrm{ml})$ was added drop wise with constant shaking in order to ensure thorough mixing. The reaction mixture was shaken occasionally and allowed to stand at room temperature for overnight. The solid mass obtained was separated by filtration, washed with water and dried. The white crystals obtained were crystallized from a mixture of chloroform and alcohol (2:1) (M.P. $215-216^{\circ} \mathrm{C}$ ).

Mol. Formula: $\mathrm{C}_{23} \mathrm{H}_{18} \mathrm{~N}_{3} \mathrm{SBr}$

Observed: $\mathrm{C}=61.34 ; \mathrm{H}=4.02 ; \mathrm{N}=9.4 \%$, Calculated: $\mathrm{C}=\wedge 1.60 ; \mathrm{H}=4.01 ; \mathrm{N}=9.37 \%$

IR: $v_{\max }(\mathrm{KBr}): 2980,1600,1530,1440,1340$, 1330, 1290, 1240, 1140, 1080, 1040,, 900, 870, $820,750,680$ and $550 \mathrm{~cm}^{-1}$.

Synthesis of 3-(2'-hydroxyphenyl)-5-(4chlorophenyl)-1-(6-mrthoxybenzothiazolo)-4bromopyrazoline (II)

The 3-(2'-hydroxyphenyl)-5-(4-chlorophenyl)-1-(6methoxybenzothiazolo)-4-bromopyrazoline (0.73 g) was dissolved in hot acetic acid $(40 \mathrm{ml})$. After cooling, bromine $(0.3 \mathrm{ml})$ in acetic acid $(10 \mathrm{ml})$ was added drop wise with constant shaking to ensure thorough mixing. The reaction mixture was occasionally shaken and was allowed to stand at room temperature for overnight. The solid mass separated and filtered, washed with water and dried and recrystallization from the mixture of chloroform and alcohol (2:1) afforded pale yellow crystals (M.P. $240-242{ }^{\circ} \mathrm{C}$ ).

Mol. Formula: $\mathrm{C}_{23} \mathrm{H}_{17} \mathrm{~N}_{3} \mathrm{SClBrO}_{2}$

Observed: $\mathrm{C}=61.34 ; \mathrm{H}=4.02 ; \mathrm{N}=8.10 \%$, Calculated: $\mathrm{C}=53.64 ; \mathrm{H}=3.30 ; \mathrm{N}=8.16 \%$ 
IR: $v_{\max }(\mathrm{KBr}): 3400,2920,1620,1590,1500$, $1490,1450,1410,1320,1290,1250,1180$, $1140,1030,930,900,810,760,640,550$ and $500 \mathrm{~cm}^{-1}$.

\section{Synthesis of 3-(4'-chlorophenyl)-5-(4- chlorophenyl)-1-(6-methylbenzothiazolo)-4- bromopyrazoline (III) \\ The 3-(4'-Chlorophenyl)-5-(4-chlorophenyl)-1-(6- methoxybenzothiazolo)-4-bromopyrazoline (0.73 g) was dissolved in hot acetic acid $(40 \mathrm{ml})$. After cooling bromine $(0.3 \mathrm{ml})$ in acetic acid $(10 \mathrm{ml})$ was added drop wise with constant shaking to ensure thorough mixing. The reaction mixture was occasionally shaken and allowed to stand at room temperature for overnight. The solid mass separated, washed with water and dried. Crystallization from the mixture of chloroform and alcohol (2:1) afforded greenish yellow crystals (M.P. $204{ }^{\circ} \mathrm{C}$ ). \\ Mol. Formula: $\mathrm{C}_{23} \mathrm{H}_{16} \mathrm{~N}_{3} \mathrm{SCl}_{2} \mathrm{Br}$ \\ Observed: $\mathrm{C}=61.34 ; \mathrm{H}=4.02 ; \mathrm{N}=8.08 \%$, Calculated: $\mathrm{C}=53.38 ; \mathrm{H}=3.09 ; \mathrm{N}=8.12 \%$ \\ IR: $v_{\max }(\mathrm{KBr}): 2900,1610,1590,1490,140$, $1340,1310,1200,1160,1070,910,870,830$, $820,750,680$ and $540 \mathrm{~cm}^{-1}$.}

Synthesis of 3-(4'-methylphenyl)-5-(3,4dimethoxyphenyl)-1-(6-methylbenzothiazolo)4-bromopyrazoline (IV)

The 3-(4'-methylphenyl)-5-(3, 4dimethoxyphenyl)-1-(6-methoxybenzothiazolo) pyrazoline $(1.49 \mathrm{~g})$ was dissolved in hot acetic acid $(40 \mathrm{ml})$. After cooling bromine $(0.3 \mathrm{ml})$ in acetic acid $(10 \mathrm{ml})$ was added drop wise with constant shaking to ensure thorough mixing. The reaction mixture was occasionally shaken and allowed to stand at room temperature for overnight. The solid thus separated was filtered, washed with water and dried. Crystallization from the mixture of chloroform and alcohol (2:1) afforded white crystals (M.P. $175-176{ }^{\circ} \mathrm{C}$ ).

Mol. Formula: $\mathrm{C}_{26} \mathrm{H}_{24} \mathrm{~N}_{3} \mathrm{SBrO}_{2}$

Observed: $\mathrm{C}=61.34 ; \mathrm{H}=4.02 ; \mathrm{N}=8.08 \%$, Calculated: $\mathrm{C}=59.77 ; \mathrm{H}=4.59 ; \mathrm{N}=8.04 \%$

IR: $v_{\max }(\mathrm{KBr}):$ 2920, 1600, 1570, 1530, 1490, 1440, 1320, 1260, 1240, 1100, 1020, 900,840, $820,760,730.690,630$ and $550 \mathrm{~cm}^{-1}$.

Synthesis of 3-(2'-hydroxylphenyl)-5-phenyl1-(6-methoxybenzothiazolo)-4bromopyrazoline(V)

The 3-(2'-Hydroxylphenyl)-5-phenyl-1-(6methoxybenzothiazolo) pyrazoline $(0.67 \mathrm{~g})$ was dissolved in hot acetic acid $(40 \mathrm{ml})$. After cooling bromine $(0.3 \mathrm{ml})$ in acetic acid $(10 \mathrm{ml})$ was added drop wise with constant shaking to ensure thorough mixing. The reaction mixture was occasionally shaken and was allowed to stand at room temperature overnight. The solid mass separated, washed with water and dried. Crystallization from the mixture of chloroform and alcohol (2:1) afforded yellow crystals (M.P. 241-242 ${ }^{\circ} \mathrm{C}$ ).

Mol. Formula: $\mathrm{C}_{23} \mathrm{H}_{18} \mathrm{~N}_{3} \mathrm{SO}_{2} \mathrm{Br}$

Observed: $\mathrm{C}=61.34 ; \mathrm{H}=4.02 ; \mathrm{N}=8.08 \%$, Calculated: $\mathrm{C}=57.50 ; \mathrm{H}=8.75 ; \mathrm{N}=16.66 \%$

IR: $v_{\max }(\mathrm{KBr}): 3360,2900,1620,1590,1520$, 1460, 1330, 1270, 1250, 1180, 1160, 1040, 930, $900,810,760$, and $530 \mathrm{~cm}^{-1}$.

$\left(\mathrm{CDCL}_{3}\right): \delta 3.30(1 \mathrm{H}, \mathrm{dd}, \mathrm{C}-\mathrm{H}), \delta 3.80(3 \mathrm{H}, \mathrm{s}$, $\left.\mathrm{OCH}_{3}\right), \delta 5.70(1 \mathrm{H}, \mathrm{dd}, \mathrm{C}-\mathrm{H}), \delta 6.90$ to $7.7(12 \mathrm{H}$, $\mathrm{m}, \mathrm{Ar}), \delta 10.70(1 \mathrm{H}, \mathrm{s}, \mathrm{OH})$.

\section{Results and Discussion}

The structures of these products have been established by spectral and analytical studies. The PMR spectra of pyrazolines showed doublets for each $-\mathrm{CH}_{2}$ proton between $\delta 2.25$ and $\delta 3.60$ and $\delta 3.90$ and $\delta 4.00$, and double doublet between $\delta 5.25$ and $\delta 6.20$ for $-\mathrm{CH}$ - protons. However in PMR spectra of bromo-benzothiazolopyrazolines, the signal between $\delta 3.90$ to $\delta 4.00$ is absent, which provides the conclusive evidence that electrophilic attack of bromine takes place at C-4 of the pyrazoline nucleus. The mass spectrum of 3-(2'-hydroxylphenyl)-5-phenyl-1-(6methoxybenzothiazolo)-4-bromopyrazoline exhibits the molecular ion peak at $\mathrm{m} / \mathrm{z} 480$, which is the molecular weight of the compound.:

\section{Antibacterial Activity}

The synthesized compounds were assayed against human pathogens like gram positive $S$.aureus and $B$. subtilis and gram negative E.coli and S.typhi by agar cup plate method [8] at concentration of $40 \mu \mathrm{g} / \mathrm{ml}$ in solvent DMF using nutrient agar medium. The zone of inhibition was measured in $\mathrm{mm}$. Under similar conditions control experiment was carried out using Streptomycin, Chloramphenicol and Penicillin. It was found that most of these compounds were found active against all bacteria except gram negative $E$. coli.

\section{References}

[1] Holla B. S., Shivnanda M. K., Akberali P. M. and Shenoy M. S. (2000) Indian J. Chem., 39B, 440.

[2] Sorathia S. D., Patel V. B. and Parikh A. R. (1997) Indian J. Chem., 36B, 630.

[3] Desai J. K. and Ankhiwala M. D. (1997) J. Inst. Chem. (India), 69, 27.

[4] Desai M. D. and Desai K. K. (2002) Asian J. Chem., 14(2), 995.

[5] Ankhiwala M. D. and Naik H. B. (1990) J. Indian Chem. Soc., 67, 258.

[6] Ankhiwala M. D. (1990) J. Indian Chem. Soc., 67, 514.

[7] Pathak Vishal, Kumar Bharat and Tiwari I. C. (2009) J. Chemtracks, 11(2), 469.

[8] Simoncini F., Rangone R. and Calani C., Formaco. Ed., Pract. 23, 559 (1968) Chem Abstr., 1968, 69, 109851d. 
Table 1- Comparable antimicrobial activity with known chosen standard drugs

\begin{tabular}{|c|c|c|c|c|c|c|}
\hline Standard drugs & Compd. & \multicolumn{2}{|c|}{ Gram positive } & \multicolumn{3}{|c|}{ Gram negative } \\
\hline & & S.aures & B. subtilis & E. coli & S. typh & \\
\hline & $\mathrm{I}$ & 10 & 14 & NA & 11 & \\
\hline & II & 13 & 9 & NA & 12 & \\
\hline & III & 11 & 12 & NA & $! 0$ & \\
\hline & IV & 14 & 12 & 10 & 13 & \\
\hline & $\mathrm{V}$ & 19 & 16 & 12 & 14 & \\
\hline Norfloxacin & & 27 & 25 & & & 25 \\
\hline Ampicillin & & 22 & 23 & & & 18 \\
\hline Chloronphenicol & & 20 & 27 & & & 20 \\
\hline
\end{tabular}

